\title{
Characteristics of the Pedagogical Model for Forming Social Responsibility in Students by Means of Project Technologies
}

\author{
Vainola Renate (Ukraine) \\ Doctor of Pedagogical Sciences, Professor \\ Dragomanov National Pedagogical University (Ukraine, Kyiv)
}

\author{
Xi Zechen (China) \\ Postgraduate student \\ Dragomanov National Pedagogical University (Ukraine, Kyiv)
}

\begin{abstract}
The article describes the essence and components of the pedagogical model for forming social responsibility in students by means of project technologies. Determined the structural components of this pedagogical model: the purpose, tasks, principles, pedagogical conditions, criterion principles (criteria, indicators and levels of formation), technological support of project activity, result. Characterized the principles of forming social responsibility of students: personal orientation of educational process, dialogicity (conventionalized), integrativeness, nonlinearity, on becoming a person.

Defined the criteria of forming social responsibility of students and the corresponding indicatorsindicators of their display. Presented four levels (insufficient, satisfactory, sufficient and optimal) for forming certain indicators. The leading means of realization of the pedagogical model for forming social responsibility of students is defined by design technologies, their characteristics in the context of the concept of projective education. Project technologies are defined as a set of forms, methods, means of educational influence in order to implement forecasting, resource development and methodological support of project activities.

Key words: model, pedagogical model, social responsibility, formation of social responsibility, pedagogical conditions, project, project technologies, institution of higher education, students.

Актуальність дослідження. Актуальність пошуку ефективних шляхів розвитку соціальної відповідальності студентів обумовлена сучасним вектором освітньої політики, що визначає орієнтацію на соціалізацію особистості, яка здатна і готова нести відповідальність за особисте і за суспільне благополуччя в своїй майбутній професійній діяльності. Саме тому одним із пріоритетних напрямків освіти $\epsilon$ виховання відповідальних громадян, що здатні до свідомого суспільного вибору, спрямування своє діяльності на користь іншим людям та суспільству. Реалії сьогодення вимагають розвитку у студентської молоді свідомого ставлення до розбудови суспільства та соціальних відносин, вміння приймати рішення у нестандартних ситуаціях та нести за них відповідальність. Ці завдання підтверджують необхідність розробки моделі формування соціальної відповідальності студентів в умовах закладу вищої освіти.
\end{abstract}


Головним засобом реалізації завдання формування соціальної відповідальності студента визначено технології соціального проєктування.

Аналіз наукової літератури з практики соціально-виховної роботи дали змогу відзначити, що нині залишається поза увагою вивчення проблеми формування соціальної відповідальності студентської молоді засобами проєктної діяльності. Тому метою нашої статті визначено обгрунтування сутності та складових педагогічної моделі формування соціальної відповідальності студентів засобами проєктних технологій.

Виклад основного матеріалу. Більшість дослідників процесу моделювання схиляються до думки, що ефективна та якісна організація виховної роботи закладу вищої освіти можлива лише за умови моделювання, прогнозування та моніторінгу процесу виховання особистості. Завдяки моделюванню можна конструювати процес соціальновиховної роботи, визначати динаміку формування особистісних утворень, а також прогнозувати майбутній розвиток показників сформованості соціальної відповідальності студентів.

3 метою розробки педагогічної моделі формування соціальної відповідальності студентів засобами проєктних технологій ми визначили іï структурні складові: мету, завдання, принципи, педагогічні умови, критеріальні засади (критерії, показники і рівні сформованості), технологічне забезпечення проєктної діяльності, результат.

Метою моделі визначено формування соціальної відповідальності студентів. Як результат реалізації даної моделі ми оцікували отримати підвищення рівня сформованості позаників соціальної відповідальності студентів.

Завданнями реалізації даної педагогічної моделі визначено: прогнозування змісту, напрямів та засобів формування соціальної відповідальності студентів; розробка та упровадження педагогічних умов формування соціальної відповідальності студентів; розробка технологій соціального проєктування, як провідного засобу формування соціальної відповідальності студентів.

Ми вважали за доцільне визначити та схарактеризувати принципи формування соціальної відповідальності, що надалі суттєво визначили характер, спрямованість нашого дослідження, і відповідно, були закладені в основу авторської педагогічної моделі.

Першим принципом постає особистісна зорієнтованість освітнього процесу, 
щзо трактується як увага до суб'єктності, сприяння розвитку особистості студента. На практиці ця ідея означає побудову горизонтальних зв'язків співпраці. У світлі цих міркувань зазначимо, що цілі освіти стають не тільки багатопрофільними, а й багаторівневими; обов'язковим елементом освітнього процесу стає внутрішня диференціація. Замість однієї загальної траєкторії педагог змушений вибудовувати безліч індивідуальних траєкторій розвитку особистості студента, які ведуть в необхідному для кожного студента напрямі, що й визначає зростання його відповідальності.

Принцип діалогічності (конвенціональності), який передбачає встановлення взаємодомовленостей, гармонії в діалозі кількох позицій, підходів, ідей, точках зору став важливим під час аналізу феномену соціальної відповідальності на основі різних світоглядних позицій.

Застосування принципу інтегративності обумовлено багатофакторністю та багатокомпонентністю процесу розвитку вивчаємого особистісного утворення, включенням багатьох сфер гуманітарних знань в зміст, форми та методи освітнього процесу, що забезпечує результативність формування соціальної відповідальності студента. Цей принцип знаходить свій відбиток в інтеграції ряду особистісних якостей, характерологічних властивостей в структуру соціально відповідальної особистості.

Принцип нелінійності визнає використання багатоваріантності шляхів розвитку особистості. Він базується на розгляді особистості студента як складної нелінійной сутності, наділеної певним ступенем свободи, гнучкості мислення та дій, шо допомагають ій адаптуватись в складних соціальних умовах.

Принцип становлення передбачає розгляд явища формування соціальної відповідальності студента в розрізі еволюційного процесу, неперервності та динаміки. Застосування даного принципу в контексті нашого дослідження обумовлено тим, що формування соціальної відповідальності особистості можна розглядати як еволюційне восходження особистості до більш складних соціальних форм іï життєдіяльності, що відбувається на певних життєвих циклах.

Таким чином, реалізація принципів особистісної зорієнтованості освітнього процесу, діалогічності, інтегративності, нелінійності та становлення дозволила нам розглядати проблему формування соціальної відповідальності студентів в комплексі, 
взаємодії цілої низки філософських підходів та соціогуманітарних наук, більш рельєфно уявити його сутність, специфіку, цілісність, виявити педагогічні умови реалізації завдань нашого дослідження.

Ще однією складовою педагогічної моделі формування соціальної відповідальності студентів засобами проєктних технологій стали критеріальні засади (критерії, показники і рівні сформованості). Нами визначено критерії формування соціальної відповідальності студентів і відповідні показники-індикатори їх прояву: когнітивний (усвідомлення сутності та специфіки соціальної відповідальності, та іï проявів; вміння аналізувати соціальні, моральні і професійні ситуації, якості та оцінювати їх з позицій власних сформованих моральних принципів); оціночно-емоційний (готовність до оцінки соціальних явищ, до об'єктивних оціночних суджень, самозвіту та самооцінки; емоційна стійкість, відкритість та здатність до емпатії); світоглядний (системність соціальних ставлень та соціально-схвальних переконань; трансформація переконань в особистісні якості студентів (незалежність, самостійність, об'єктивність, організованість тощо); поведінковий (активна життєва і громадянська позиції, що знаходять практичне підтвердження; участь в суспільно значущих громадських справах групи, закладу освіти, громади). Оцінка сформованості визначених критеріїв та показників здійснюється на чотирьох рівнях: недостатньому, задовільному, достатньому та оптимальному.

Важливою складовою нашої моделі визначено засоби формування соціальної відповідальності студентів. Провідним засобом визначено проєктні технології. Саме тому ми вважали за доцільне обгрунтувати засади даної діяльності і зупинитися на визначеннях «проєкт», «проєктування» та «проєктна технологія».

Трактування поняття «проєкт» знайшло науково-теоретичне та технологічне обгрунтування на початку XX століття, у перекладі з латинської мови (projectus) означає «кинутий уперед». Проєкт в словниковій літературі переважно трактується як задум, система планування, концепція, діяльність по створенню прототипу, прообразу передбачуваного об’єкта [7]. Термін «проєктування» розглядається як діяльність по створенню та впровадженню проєкту, тобто як метод, що використовувалося як в освітній сфері, так і в технічних галузях людської діяльності (інженерному проєктуванні, конструюванні речей, машин та комунікацій). Проєктування у 
словниковій літературі визначається як здатність намічати, окреслювати план дій, конструювати, планувати та здійснювати задум, намір [7].

Педагогічне проєктування ми розглядали і надалі трактували як один 3 видів соціального проєктування [5]. Ознаками такого виду проєктування є: наявність проєктного задуму (покладання і творення нового об'єкта, нових його якостей і станів); проєктна конструктивізація (розробка специфічною проєктною мовою задуму об'єкта, що передбачає процедури аналізу, синтезу, конструювання, узгодження, конкретизації тощо); спрямованість на проєктну реалізацію (як можливість створення за проєктом нового об'єкту, яка може і не здійснитися); проєктна онтологія (відчуття зв'язку проєктування з практичною діяльністю, належність до цінностей проєктної свідомості тощо). У педагогічному проєктуванні процедури аналізу та синтезу виводять проєктувальника за межі проєктної реальності до інших галузей і дисциплін, при цьому його головною метою є освітня.

В основу розробки нашої педагогічної моделі формування соціальної відповідальності студентів засобами проєктних технологій покладено концепцію проєктивної освіти Г. Ільїна, сутність якої полягає в тому, що суб'єктом навчання стає сама людина, оскільки вона не тільки набуває знання, а й сама створює власне бачення навколишнього світу [4]. Освіта стає для студента проєктуванням іiі життєдіяльності. Організація освітнього середовища постає як задумом, проєкт, який здобувач освіти формує і прагне реалізувати завдяки активній, усвідомленій участі і освітньому процесі.

У закладі вищої освіти проєктні технології стали складовою сучасних інноваційних педагогічних технологій у контексті особистісно орієнтованої вищої освіти $[1 ; 2 ; 3 ; 6]$. Дана група технологій відображає сукупність прийомів, дій студента та науково-педагогічного працівника закладу для досягнення поставленого завдання вирішення певної проблеми, яка має значення для них та оформлена у вигляді продукту - дослідницької, проєктної, творчої розробки. Проєктні технології надають можливість студентам самостійно отримати знання у процесі вирішення практичних завдань або проблем, які потребують інтеграції знань із різних галузей наук. Педагоги під час використання цього методу виступають у ролі розробників завдань для інноваційного проєкту, координаторів, експертів, консультантів тощо.

Технологічне забезпечення проєктної діяльності як провідного засобу формування 
соціальної відповідальності студентів утворили форми та методи роботи (виховні інтерактивні години, кейси, творчі захистиг та соціальні проєкти) [3]. Проєктні технології ми визначили як сукупність форм, методів, засобів виховного впливу з метою здійснення прогнозування, розробки ресурсів та методичного забезпечення проєктної діяльності.

Узагальнюючи підходи до визначення педагогічних умов, що оптимізують процес формування соціальної відповідальності студентів в умовах закладу вищої освіти, доцільно виділити такі:

- удосконалення форм соціально-виховної роботи, збільшення частки форм, оріснтованих на усвідомлення та прийняття цінностей соціальної відповідальності;

- $\quad$ моделювання навчальних i виробничих ситуацій, пов'язаних 3 необхідністю соціально-відповідальних дій;

- застосування технологій проєктування з метою залучення студентів до соціально значущої діяльності.

Висновки. Таким чином, нами здійснено обгрунтування сутності та складових педагогічної моделі формування соціальної відповідальності студентів засобами проєктних технологій. Розробка даної моделі дозволила нам розгорнути експериментальну роботу з упровадження педагогічних умов формування соціальної відповідальності студентів засобами проєктних технологій.

\section{References}

1. Vainola R.Kh. Klasyfikatsiyni pidkhody do kharakterystyky tekhnolohiy sotsialnoyi ta sotsialno-pedahohichnoyi roboty. Naukovyy chasopys NPU imeni M. P. Drahomanova. 2008. Pp. 12-18. URL: http://enpuir.npu.edu.ua/bitstream/123456789/7259/1/Vaynola.pdf

2. Vainola R. Kh. Tekhnolohiyi sotsialno-pedahohichnoyi roboty [Technologies of social and pedagogical work.]. Kyyiv: KMPU imeni B. D. Hrinchenka, 2008. 152 p.

3. Vainola R. Kh. Rozvadovska T. V. Formuvannia vidpovidalnosti studentskoi molodi zasobamy nastavnytstva: metodychni rekomendatsii [Formation of responsibility of student youth by means of mentoring: methodical recommendations]/ za zah. red. R. Kh. Vainoly. Ternopil: Osadtsa Yu. V., 2021. 100 p.

4. Ilin H. L. Proektyvnoe obrazovanye y stanovlenye lichnosty [Projective education and personality formation]. Vysshee obrazovanye v Rossii. 2001. No. 4. Pp. 85-93.

5. Kolot A. M. Sotsialna vidpovidalnist: teoriia i praktyka rozvytku : monohrafiia [Social responsibility: theory and practice of development: a monograph]. Kyiv: KNEU, 2012. $501 \mathrm{p}$. 
6. Petko L. V. Vyklyky XXI stolittia dlia osvitnoho prostoru Ukrainy []. Naukovi pratsi

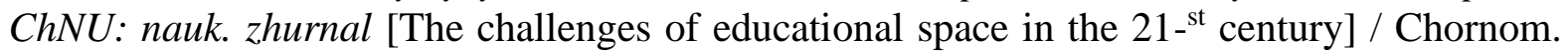
Nats. un-t im. Petra Mohyly; red. Kol.: O.P.Meshchaninov (holova) [ta in.]. - Mykolaiv: Vydvo ChNU imeni Petra Mohyly, 2017. Issue 303. Vol. 291. Pp. 10-14 (Pedahohika).

7. Psykholohichna entsyklopediia [Psychological encyclopedia] / avt.-upor. O. M. Stepanov. Kyiv: Akademvydav, 2006. 424 p.

Translation of the Title, Abstract and References to the Author's Language

УДК 37.013.42:378.014.533

Вайнола Р., Сі Цзечень. Характеристика педагогічної моделі формування соціальної відповідальності студентів засобами проєктних технологій.

У статті здійснено обгрунтування сутності та складових педагогічної моделі формування соціальної відповідальності студентів засобами проєктних технологій. Визначено структурні складові даної педагогічної моделі: мету, завдання, принципи, педагогічні умови, критеріальні засади (критерії, показники і рівні сформованості), технологічне забезпечення проєктної діяльності, результат. Охарактеризовано принципи формування соціальної відповідальності студентів: особистісної зорієнтованості освітнього процесу, діалогічності (конвенціональності), інтегративності, нелінійності, становлення. Обгрунтовано критерії формування соціальної відповідальності студентів і визначено відповідні показники-індикатори їх прояву. Зазначено, що оцінка сформованості визначених показників здійснюється на чотирьох рівнях: недостатньому, задовільному, достатньому та оптимальному. Провідним засобом реалізації педагогічної моделі формування соціальної відповідальності студентів визначено проєктні технології, здійснена їх характеристика в контексті концепції проєктивної освіти. Проєктну діяльність охарактеризовано як «проєктування», тобто діяльність по створенню та впровадженню проєкту, Проєктні технології визначено як сукупність форм, методів, засобів виховного впливу з метою здійснення прогнозування, розробки ресурсів та методичного забезпечення проєктної діяльності.

Ключові слова: модель, педагогічна модель, соціальна відповідальність, формування соціальної відповідальності, педагогічні умови, проєкт, проєктні технології, заклад вищої освіти, студенти.

\section{Література}

1. Вайнола Р.Х. Класифікаційні підходи до характеристики технологій соціальної та соціально-педагогічної роботи. Науковий часопис НПУ імені М.П.Драгоманова. URL: http://enpuir.npu.edu.ua/bitstream/123456789/7259/1/Vaynola.pdf

2. Вайнола Р. Х. Технології соціально-педагогічної роботи. Київ: КМПУ імені Б. Д. Грінченка, 2008. 152 с.

3. Вайнола Р. Х. Розвадовська Т. В. Формування відповідальності студентської молоді засобами наставництва: методичні рекомендації / за заг. ред. Р. Х. Вайноли. Тернопіль: Осадца Ю. В., 2021. 100 с.

4. Ильин Г. Л. Проективное образование и становление личности. Высшее 
образование в России. 2001. № 4. С. 85-93.

5. Колот А. М. Соціальна відповідальність: теорія і практика розвитку: монографія. Київ: КНЕУ, 2012. 501 с.

6. Петько Л. В. Виклики XXI століття для освітнього простору України. Наукові праці [Чорноморського державного університету імені Петра Могили комплексу "Києво Могилянська академія"]. Серія : Педагогіка : наук. журн. / Чорном. держ. ун-т імені Петра Могили; ред. кол. : О. П. Мещанінов (голова) [та ін.]. - Миколаїв: Вид-во ЧНУ імені Петра Могили, 2017. Т. 303. Вип. 291. С. 10-14.

7. Психологічна енциклопедія / авт.-упор. О. М. Степанов. Київ: Академвидав, 2006. $424 \mathrm{c}$. 